\title{
SEROLOGICAL SURVEY OF HANTAVIRUS IN RODENTS IN UBERLÂNDIA, MINAS GERAIS, BRAZIL
}

\author{
Jean Ezequiel LIMONGI(1,2), Fernando Guimarães MOREIRA(1), Joel Batista PERES(1), Akemi SUZUKI(3), Ivani Bisordi FERREIRA(3),
} Renato Pereira SOUZA(3), Rogério Melo Costa PINTO(2) \& Luiz Eloy PEREIRA(3)

\begin{abstract}
SUMMARY
We conducted a serological survey to determine the presence of hantavirus infection in rodents in Uberlândia, Minas Gerais as well as to identify and characterize associated factors. Rodents were captured using Sherman live-capture traps set in rural and periurban environments. A total of 611 rodents were captured. There was a higher trap success in peri-urban areas (26.3\%) and a higher prevalence of antibodies among rodents captured in rural areas (2.9\%). Necromys lasiurus was the most common species (42.2\%) and the more frequently infected $(4.6 \%)$. One Calomys tener $(1 / 141 ; 0.7 \%)$ and one Calomys sp. $(1 / 14 ; 7.1 \%)$ were also positive for the hantavirus infection. In $N$. lasiurus, antibody prevalence correlated with population density $(p<0.01)$, age class $(p=0.003)$ and presence of scars $(p=0.02)$. The data confirm that horizontal transmission is the main mechanism that maintains the virus in nature. The higher seropositivity in $N$. lasiurus is consistent with genetic studies that associate this species with an Araraquara virus reservoir; the seropositivity of $C$. tener and Calomys sp. may indicate the occurrence of spillover infection or the presence of other circulating hantaviruses.
\end{abstract}

KEYWORDS: Hantavirus; Rodentia; Brazil.

\section{INTRODUCTION}

Several rodent species in the Americas constitute a reservoir for distinctive strains of hantavirus, with high levels of species specificity among them ${ }^{16}$. To date, five hantavirus strains have been associated with Hantavirus Cardiopulmonary Syndrome (HCPS) in Brazil: Juquitiba/ Araucaria, Araraquara, Laguna Negra, Castelo dos Sonhos, and Anajatuba. Two other strains, Rio Mearim and Jabora, have been identified but their roles in human disease have not been established ${ }^{11,12,13,15}$.

In Brazil, > 1,200 cases of HCPS have been confirmed since 1993 (case-fatality rate $39 \%$ ). More HCPS cases were reported in Minas Gerais than in any other state in Brazi ${ }^{10}$. Genetic studies associated HCPS cases with hantavirus Araraquara, possibly the most virulent of Brazilian hantaviruses, and identified the wild rodent Necromys lasiurus as a reservoir of this virus ${ }^{5,15}$. We recently reported asymptomatic human infections in this area ${ }^{8}$. We have now conducted a serological survey to reveal hantavirus infection in rodents and to further understand its ecoepidemiology in an important endemic area in Minas Gerais, Brazil.

\section{MATERIAL AND METHODS}

Uberlândia in the state of Minas Gerais, southeastern Brazil (18 $18^{\circ} 07^{\prime \prime} \mathrm{S}, 48^{\circ} 16^{\prime} 38^{\prime \prime}$ WGR) average altitude of $863 \mathrm{~m}$ above sea level, comprises a population of 622,000 ; covering $4000 \mathrm{~km}^{2}$, with an urban area of $135 \mathrm{~km}^{2}$, located in the Cerrado biome, the South American savannah, characterized by a subtropical climate with two well-defined seasons, a dry winter (between May and September) and a rainy summer (between October and April). The mean annual temperature is $22^{\circ} \mathrm{C}$ and precipitation $1650 \mathrm{~mm}$ (Fig. 1.).

Rodents were trapped by using Sherman live-capture traps (Sherman Traps Inc., Tallahassee, FL) set in rural and peri-urban environments, around the presumed sites of HCPS cases, and in natural rodent habitat sites, from August 2000 until February 2002. Permits for field collection were provided by IBAMA (Brazilian Institute of Environment and Renewable Natural Resources) (Protocol number: 140/2000 and $328 / 2001)$. All the captured rodents were processed in the field following established biosafety guidelines ${ }^{9}$. Blood samples were drawn from the retro-orbital sinus using heparinized capillary tubes and stored in liquid nitrogen for further processing ${ }^{9}$. The carcasses were brought to the laboratory where the skin, cuspid teeth and cranium were used for further identification of the specimens. An ELISA (enzyme linked immunosorbent assay) was performed to detect specific IgG antibodies in serum, using Sin nombre virus antigen (supplied by T.G. Ksiazek, Centers for Disease Control and Prevention, Atlanta, GA ${ }^{6}$.

Chi-square and binomial tests were applied to compare proportions, using EPI INFO 3.3.2 (www.cdc.gov/epiinfo) and BIOSTAT 5.0 (www. biostat.org) software. Odds ratio (OR) and $95 \%$ confidence intervals were

(1) Centro de Controle de Zoonoses de Uberlândia, Uberlândia, MG, Brazil.

(2) Instituto de Ciências Biomédicas, Universidade Federal de Uberlândia, Uberlândia, MG, Brazil.

(3) Seção de Vírus Transmitidos por Artrópodos, Instituto Adolfo Lutz, São Paulo, SP, Brazil.

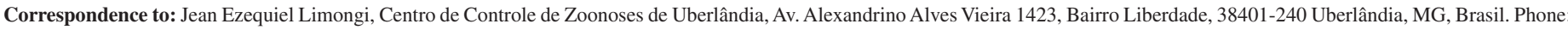
5511 3213-1470. E-mail: jeanlimongi@gmail.com 


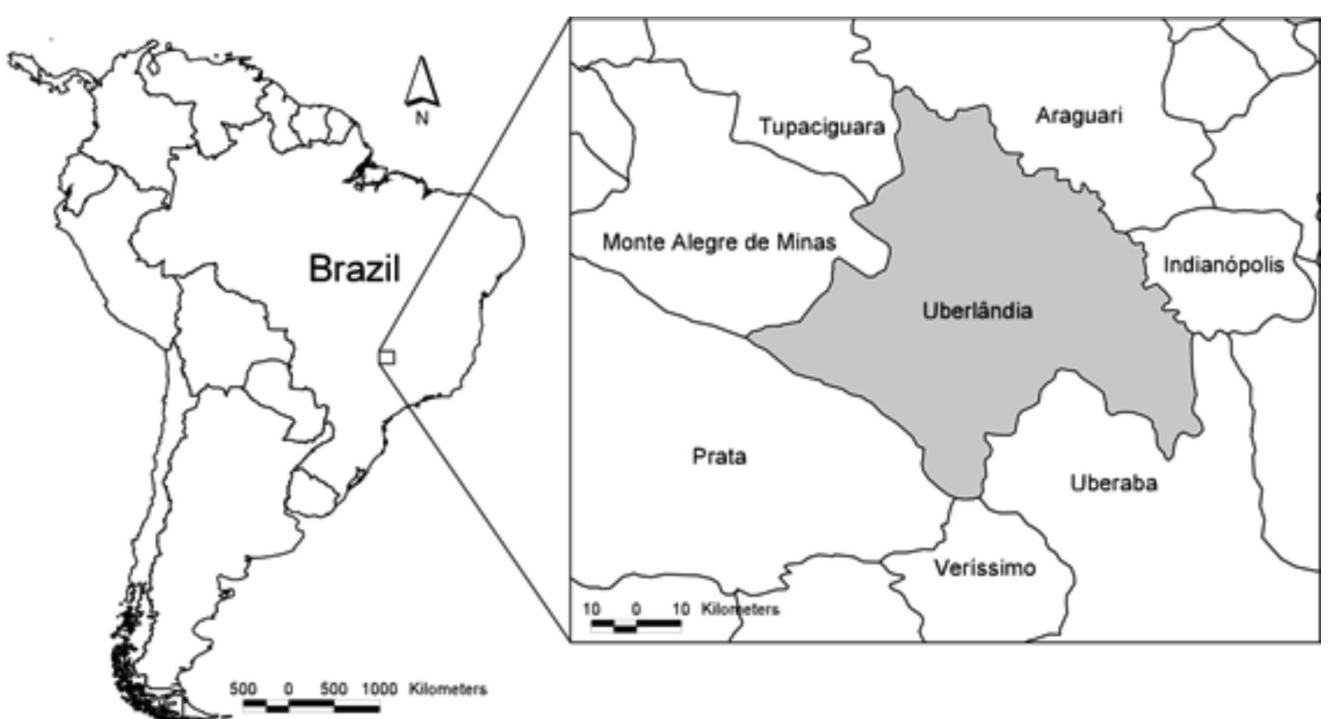

Fig. 1 - Location of the study area in Brazil (box) and detail of study area showing municipalities.

used to quantify the correlation between the risk factors of age class, sex and presence of scars, and the hantavirus infection.

\section{RESULTS AND DISCUSSION}

A total of 611 rodents were captured, 3,122 trap nights set in a rural area caught 411 rodents (trap success: $13.2 \%$ ) and 12 were antibodypositive for hantavirus (prevalence $2.9 \%$ ); in the peri-urban area, 760 trap nights caught 200 rodents (trap success: 26.3\%) and two were antibody-positive (prevalence 1.3\%). The 44 Mus musculus (Murinae) captured were not analyzed, because the viruses of the Bunyaviridae family are not associated to the Murinae sub-family rodents. Forty-four rodents captured in the peri-urban area were $N$. lasiurus, including the ones which were positive for the hantavirus antibody.

$N$. lasiurus was the most common species $(258 / 611 ; 42.2 \%)$, followed by Calomys tener $(141 / 611 ; 23.1 \%)$, Akodon spp $(82 / 611 ; 13.4 \%)$, and Calomys sp. (14/611; 2.3\%). Only a few Oligoryzomys nigripes (5/611; $0.8 \%)$, Euryoryzomys sp. $(4 / 611 ; 0.7 \%)$ and Pseudoryzomys simplex $(3 / 611 ; 0.5 \%)$ were caught. Other species included 102 M. musculus and two Rattus rattus, which are synanthropic rodents (sub-family Murinae) occasionally found in sylvan environments. The overall hantavirus seroprevalence was $2.5 \%$ for a total sample of 567 rodents analyzed. $N$. lasiurus were more frequently infected than other species $(12 / 258$; $4.6 \%)$. One C. tener $(1 / 141 ; 0.7 \%)$ and one Calomys sp. $(1 / 14 ; 7.1 \%)$ were also positive for the hantavirus antibody.

Antibody seroprevalence in N. lasiurus was distributed differentially among samplings $(p<0.01)$, with a minimum in winter $2000 / 2001$ $(1.1 \%, \mathrm{n}=188)$, when population density was high, and a maximum in summer 2001/2002 $(14.3 \%, \mathrm{n}=70)$, when density was low (Table 1$)$. The low antibody seroprevalence in winter may have resulted from the low number of adults (with a high seroprevalence) within a dense population composed mostly of juvenile individuals (not infected). Conversely, in summer the population was composed mainly of adults, which contributed to the high seroprevalence. This was also observed in Argentina where the highest population density of adults of Akodon azarae contributed to increased seroprevalence ${ }^{14}$. More complex relationships probably exist between density and prevalence, in spite of the negative correlation. However, even if there is no density-prevalence relationship, density is still a likely determinant of HCPS risk, since higher host density results in higher infected host density even if the prevalence remains constant.

Table 1

Trap success rate, characteristics and seroprevalence for hantavirus in rodents in the municipality of Uberlândia, Minas Gerais, Brazil, 2000-2002

\begin{tabular}{|c|c|c|c|c|c|c|c|c|c|}
\hline Trapping period & Trap nights & Captures & Trap success & $\begin{array}{l}\text { Adult } \\
(\%)\end{array}$ & $\begin{array}{l}\text { Female } \\
(\%)\end{array}$ & $\begin{array}{l}\text { Pregnant } \\
(\%)\end{array}$ & $\begin{array}{l}\text { Overall prev } \\
(\%)\end{array}$ & Number $\mathrm{Nl}^{\mathrm{b}}$ & $\begin{array}{l}\text { Prev Nl } \\
(\%)\end{array}$ \\
\hline Winter 2000 & 442 & 124 & 28.1 & 50 & 42 & 2 & 0 & 60 & 0 \\
\hline Summer 2001 & 1400 & 179 & 12.8 & 55 & 40 & 9 & 3.4 & 61 & 9.8 \\
\hline Winter $2001^{\mathrm{a}}$ & 1080 & 277 & 25.6 & 25 & 33 & 4 & 1.7 & 128 & 1.6 \\
\hline Summer 2002 & 960 & 31 & 3.2 & 65 & 51.6 & 26 & 12.9 & 9 & 44.4 \\
\hline Total & 3882 & 611 & 15.7 & 41 & 38 & 6 & 2.5 & 258 & 4.6 \\
\hline
\end{tabular}

${ }^{\mathrm{a}} 16 \%$ (44/277) of the captured rodents were Mus musculus, but were not analyzed by ELISA in this trapping period. ${ }^{\mathrm{b}} \mathrm{Nl}$, Necromys lasiurus. 
In the study area higher hantavirus seroprevalence in rodents occurs during the summer while the HCPS cases occur mainly in autumn/winter. During the period of 1998 to $200591 \%$ of HCPS cases were registered between May and July. Grain harvesting, dry weather and lack of food for rodents in sylvan environments during autumn/winter are likely factors for the seasonality of HCPS in this region due to increased human-rodent contact $^{7}$. The lack of correlation between antibody prevalence in rodents and HCPS cases was also observed in Argentina ${ }^{4}$.

As shown in Table 1, the number of pregnant females is higher in the study area during summer, the rainy season. As previously reported the higher food availability favors rodent reproduction and the consequent increase in population ${ }^{2}$.

Previous studies of rodent hantavirus reservoirs showed that the prevalence of infection is higher in adult males than in females and juveniles ${ }^{1,4}$. In our study, a significant relation to seroprevalence was found with age class, but not sex (Table 2). In fact, longer exposure to the virus with age increases the probability of being infected, suggesting that horizontal transmission is the main mechanism that maintains the virus in nature ${ }^{1,3}$.

Table 2

Distribution by sex, age class and presence of scarring of 14 hantavirus antibody-positive rodents captured in the municipality of Uberlândia, Minas Gerais, Brazil, 2000-2002

\begin{tabular}{lcll}
\hline Variables & $\begin{array}{c}\text { Seropositive } \\
\text { (Total) }\end{array}$ & $p$ value $^{\mathrm{a}}$ & OR $(95 \% \mathrm{CI})^{\mathrm{b}}$ \\
\hline
\end{tabular}

Sex

$\begin{array}{ll}\text { Male } & 9(335) \\ \text { Female } & 5(232)\end{array}$

Age class

$\begin{array}{lccc}\text { Adults } & 12(247) & 0.003 & 8.12(1.80-36.62) \\ \text { Juveniles } & 2(320) & & \end{array}$

Scars

Presence

Absence 5 (386)

${ }^{\mathrm{a}} \mathrm{p}$-values were determined by 2-tailed chi-square or binomial test for two proportions. ${ }^{\mathrm{b}} \mathrm{OR}$, Odds ratio; $\mathrm{CI}$, confidence interval.

Our analysis showed that more males than females bore ear and tail scars (58\%); mainly the adult males. Eighty-nine percent of the antibody-positive males were scarred, confirming virus transmission through aggressive behavior. In fact, according to literature, more aggressive encounters occur between male rodents than between female rodents ${ }^{1,4}$. Fighting and exchange of blood and saliva between infected and uninfected adult rodents has been recognized as the primary mechanism by which hantaviruses are amplified epizootically ${ }^{3}$. Indeed, in our work the presence of scarring was associated with seropositivity (Table 2).

The higher hantavirus antibody positivity among $N$. lasiurus is consistent with the results of previous genetic studies that associate this species with a reservoir of Araraquara virus. The seroreactivity of $C$. tener and Calomys sp. may indicate the occurrence of spillover infection or the presence of other circulating hantaviruses ${ }^{5,15}$. Molecular studies are needed in order to characterize the strains of hantavirus occurring in this area and their associated reservoirs.

\section{RESUMO}

\section{Inquérito sorológico de hantavírus em roedores, Uberlândia, Minas Gerais, Brasil}

Realizamos um estudo transversal para identificar a presença de infecção por hantavírus em roedores em Uberlândia, Minas Gerais, e também para identificar e caracterizar fatores associados. Roedores foram capturados usando armadilhas do tipo Sherman em ambientes rural e periurbano. Um total de 611 roedores foi capturado. Houve maior sucesso de captura na área periurbana $(26,3 \%)$ e maior prevalência de anticorpos entre os roedores capturados na área rural (2,9\%). Necromys lasiurus foi a espécie mais encontrada $(42,2 \%)$ e a mais frequentemente infectada (4,6\%). Um Calomys tener (1/141; $0.7 \%)$ e um Calomys sp. $(1 / 14 ; 7.1 \%)$ foram também positivos. Os dados obtidos mostram que em $N$. lasiurus, a prevalência de anticorpos está relacionada à densidade populacional $(p<0.01)$, a classe de idade $(p=0.003)$ e a presença de cicatrizes $(p=0.02)$, confirmando que a transmissão horizontal é o principal mecanismo que mantém o vírus na natureza. A maior positividade em $N$. lasiurus é consistente com estudos genéticos que permitem associar esta espécie como reservatório do vírus Araraquara; a soropositividade de C. tener e Calomys sp. pode indicar a ocorrência de "spillover infection" ou a presença de outros hantavírus circulantes.

\section{ACKNOWLEDGEMENTS}

To Paulo Sérgio D'Andrea and Cibele Rodrigues Bonvicino, for their invaluable technical support. To Jovenil Gomes da Silva (in memorian) for his support during the fieldwork.

\section{AUTHOR CONTRIBUTIONS}

Jean Ezequiel Limongi: conception and design of the study, collection, assembly, analysis and interpretation of data and drafting the article.

Fernando Guimarães Moreira: collection, assembly, analysis and interpretation of data and drafting the article.

Joel Batista Peres: collection, assembly, analysis and interpretation of data and drafting the article.

Akemi Suzuki collection, assembly, analysis and interpretation of data and drafting the article.

Ivani Bisordi Ferreira: collection, assembly, analysis and interpretation of data and drafting the article.

Renato Pereira Souza: collection, assembly, analysis and interpretation of data and drafting the article.

Rogério Melo Costa Pinto: analysis and interpretation of data and drafting the article.

Luiz Eloy Pereira: conception and design of the study, collection, assembly, analysis and interpretation of data and drafting the article. 


\section{REFERENCES}

1. Abbott KD, Ksiazek TG, Mills JN. Long-term hantavirus persistence in rodent populations in Central Arizona. Emerg Infect Dis. 1999;5:102-12.

2. Bergallo HG, Magnusson WE. Effects of climate and food availability on four rodent species in southeastern Brazil. J Mammal. 1999;80:472-86.

3. Calisher CH, Sweeney W, Mills JN, Beaty BJ. Natural history of sin nombre virus in Western Colorado. Emerg Infect Dis. 1999;5:126-34.

4. Cantoni G, Padula P, Calderón G, Mills J, Herrero E, Sandoval P, et al. Seasonal variation in prevalence of antibody to hantaviruses in rodents from southern Argentina. Trop Med Int Health. 2001;6:811-6.

5. Figueiredo LTM, Moreli ML, Sousa RLM, Borges AA, Figueiredo GG, Machado AM, et al. Hantavirus pulmonary syndrome, Central Plateau, Southeastern, and Southern Brazil. Emerg Infect Dis. 2009;15:561-7.

6. Ksiazek TG, Peters CJ, Rollin PE, Zaki S, Nichol S, Spiropoulou C, et al. Identification of a new North American hantavirus that causes acute pulmonary insufficiency. Am J Trop Med Hyg. 1995;52:117-23.

7. Limongi JE, Costa FC, Paula MBC, Pinto RMC, Oliveira ML, Pajuaba Neto AA, et al. Síndrome cardiopulmonar por hantavirus no Triângulo Mineiro e Alto Paranaíba, Minas Gerais, 1998-2005: aspectos clínico-epidemiológicos de 23 casos. Rev Soc Bras Med Trop. 2007;40:295-9.

8. Limongi JE, Costa FC, Pinto RMC, Oliveira RC, Bragagnolo C, Lemos ERS, et al. Crosssectional survey of hantavirus infection, Brazil. Emerg Infect Dis. 2009;15:1981-3.

9. Mills JN, Childs JE, Ksiazek TG, Peters CJ, Velleca WM. Methods for trapping and sampling small mammals for virologic testing. Atlanta: Centers for Disease Control and Prevention; 1995.
10. Ministério da Saúde. Brasil. SPH casos: 1993-2010. Available from: http://portal.saude. gov.br/portal/arquivos/pdf/hanta_serie_historica_1993_2010.pdf [Cited: 2011, June 25).

11. Oliveira RC, Padula PJ, Gomes R, Martinez VP, Bellomo C, Bonvicino CR, et al. Genetic characterization of hantaviruses associated with sigmodontine rodents in an endemic area for hantavirus pulmonary syndrome in southern Brazil. Vector Borne Zoonotic Dis. 2011;11:301-14.

12. Raboni SM, Hoffmann FG, Oliveira RC, Teixeira BR, Bonvicino CR, Stella V, et al. Phylogenetic characterization of hantaviruses from wild rodents and hantavirus pulmonary syndrome cases in the state of Paraná (southern Brazil). J Gen Virol. 2009;90:2166-71.

13. Rosa EST, Lemos ERS, Medeiros DBA, Simith DB, Pereira AS, Elkhoury MR, et al Hantaviruses and hantavirus pulmonary syndrome, Maranhão, Brazil. Emerg Infect Dis. 2010;16:1952-5.

14. Suárez OV, Cueto GR, Cavia R, Villafañe IEG, Bilenca DN, Edelstein A, et al. Prevalence of infection with hantavirus in rodent populations of central Argentina. Mem Inst Oswaldo Cruz. 2003;98:727-32.

15. Suzuki A, Bisordi I, Levis S, Garcia J, Pereira LE, Souza RP, et al. Identifying rodent hantavirus reservoirs, Brazil. Emerg Infect Dis. 2004;10:2127-34.

16. Yates TL, Mills JN, Parmenter CA, Ksiazek TG, Parmenter RR, Vande Castle JR, et al The ecology and evolutionary history of an emergent disease: hantavirus pulmonary syndrome. BioScience. 2002;52:989-98.

Received: 5 June 2012

Accepted: 10 October 2012 